\title{
Congenital Hamartoma
}

National Cancer Institute

\section{Source}

National Cancer Institute. Congenital Hamartoma. NCI Thesaurus. Code C40425.

A hamartomatous lesion which is present at birth. 